\title{
A MAKÓI KISRÉGIÓ NÉPESSÉGFÖLDRAJZA
}

\author{
(The population geography of the Makó small-region)
}

\section{BAJMÓCY PÉTER}

A vizsgált terület Makót, és tizenhat környezö Csongrád megyei községet foglal magában. Lehatárolásánál több tényezőt kellett figyelembe venni. Elsỏsorban a korábbi (Csanád, illetve Csanád-Arad-Torontál), valamint a jelenlegi (Csongrád) megyehatárokat. Ezen kívül az ingázási adatokat és közlekedési izokronokat tekintettük mérvadónak. A vizsgált terület végül is kiterjed mindazokra a községekre, amelyek valamilyen módon kapcsolódnak Makóhoz. A jelenlegi megyehatárt nem léptük át, mert a város vonzása ott már igen gyenge, mind a kisebb vonzáskőzpontok (Mezőhegyes, Mezökovácsháza), mind pedig a távolabbi nagyobb városok (Békéscsaba, Orosháza) vonzása erỏsebb nála.

A terület természetföldrajzilag két részre osztható. A Maros-völgy alluviális síkságát réti és öntéstalajok borítják, a nagyobb, középső, és északi részen pedig kiváló minöségủ csernozjom talaj alakult ki, amelyet csak néhány alacsonyabb, lefolyástalan helyen zạvarnak meg szikes talajfoltok. A régió az országos átlagnál melegebb és szárazabb, de a talaj és éghajlati adottságait tekintve az ország egyik legjobb mezógazdasági potenciáljával rendelkező vidéke.

A terület természeti adottságaiból adódóan elsősorban a gabonatermesztés terjedt el (föleg búza és kukorica). A takarmánygabona termesztéséhez állattenyésztés kapcsolódik, de a Maros-völgy nyugati része kivételével ez mindenütt alárendelt szerepet játszik a növénytermesztéssel szemben. Ezt azért lényeges hangsủlyozni, mert a gabonatermesztés, gépesíthetősége miatt a mezőgazdaságnak az az ága volt, amely munkaerö kibocsátóvá vált.

A terület mezőgazdaságának jellegzetes növénye a makói hagyma. A hagyma olyan növény, amely munkaigényessége alapján gazdaságosan termelhetỏ lenne, és amely képes a mezőgazdasági népesség egy részét megkötni. Termelésének, és az exporttevékenységnek az irányítása azonban egyrészt nem Makón volt, másrészt a növény jelentỏsége már a két világháború között is csökkent. Ez a trend az utóbbi évtizedekben sem módosult, a szántóból az ơsszes zőldségfélék kevesebb, mint 10\%-ot tesznek ki.

Az ipar szerepét is hangsúlyoznunk kell, hiszen a hatvanas-hetvenes években egy terület népességmegtartó kapacitása tulajdonképpen attól függött, hogy rendelkezett-e számottevő iparral vagy sem. 1979-ben a makói járás ipari foglalkoztatottjainak aránya a megyei átlag negyede, a községi átlag 80\%-a. Makó városánál ez az arány nemcsak a városi, de a megyei átlag alatt volt! Az iparra, amely szinte kizárólag Makóra koncentrálódik, leginkább a közép- illetve a kisüzemek jẹllemzőek, és ezek zöme nem makói irányítású, amely szintén hátráltatta a fejlődésüket. A 90-es években ezeket az üzemeket zárták be legelőször, így a vidéki ipar válsága, amely országos jelenség, itt is érezteti hatását.

A régió közlekedésfơldrajzi helyzetét vizsgálva rögtön szembetünik, hogy a 43-as fónt áthalad a területen, és az egyik legnagyobb magyar-román határátkelö is itt található (Nagylak). Azt mondhatnánk, megvan tehát a gazdaság fejlödésének kulcsa, ez a lehetóség, a tranzitforgalom kilendítheti ezt a területet a gazdasági mélypontról. Ha 
Tér és Társadalom 10. évf. 1996/2-3. 103-110. p.

azonban alaposabban szemügyre vesszük a forgalmat, láthatjuk, hogy ez mégsem olyan igazi húzóerő. Az útvonal távolról sem európai jelentőségủ és a forgalom nagysága legfeljebb Nagylak esetében jelenthet valamilyen fejlődési potenciált, Makónál már nem, hiszen egy ekkora várost egy ilyen méretủ tranzitforgalom nem tarthat el.

\section{A terület népességföldrajzi jellemzôi a XX. század első felében}

A makói kisrégió az I. világháború elött nagyrészt Csanád vármegyéhez tartozott, csak három település volt $\mathrm{az}$ akkori Torontál vármegye része (Kiszombor, Klárafalva, Ferencszállás). A megye székhelye Makó volt. A török kor alatt a terület nagy része elnéptelenedett, csak Makó maradt meg, mint önálló település, de a környező, elnéptelenedö községekböl jelentősen növelte népességét. A régió többi települése a XVIII.-XIX. században keletkezett (pl. Ambrózfalva, Csanádalberti 1844, Földeák 1847). A régió népessége gyorsan növekedett, 1870-ben 52000, még 1900-ban 66000 ember élt a vizsgált területen. Ez 30 év alatt 29\%-os növekedést jelentett, amely csak valamivel kevesebb, mint az országos és a dél-alföldi átlag (32\%) (I. táblázat).

\section{TÁBLÁZAT}

Népességszám alakulása a makói kisrégióban (1870-1994)

(The change of the population in the Makó small-region, 1870-1994)

\begin{tabular}{|l|r|r|r|r|r|r|r|r|r|r|r|r|r|r|}
\hline Település & 1870 & 1880 & 1890 & 1900 & 1910 & 1920 & 1930 & 1941 & 1949 & 1960 & 1970 & 1980 & 1990 & 1994 \\
\hline Makó & 26900 & 29135 & 31654 & 32707 & 33249 & 36265 & 35143 & 34873 & 33068 & 31703 & 30274 & 29942 & 27529 & 26424 \\
\hline Ambrózfalva & 861 & 866 & 1006 & 1041 & 1042 & 1063 & 1025 & 1008 & 743 & 689 & 589 & 581 & 555 & 526 \\
\hline Apátfalva & 4000 & 4274 & 5158 & 5318 & 5642 & 5741 & 5581 & 5773 & 5584 & 5322 & 4826 & 4361 & 3704 & 3566 \\
\hline Csanádalberti & 836 & 886 & 1028 & 1233 & 1370 & 1377 & 1460 & 1510 & 999 & 1065 & 711 & 606 & 528 & 475 \\
\hline Csanádpalota & 4052 & 4483 & 5271 & 5584 & 5811 & 5928 & 5718 & 5939 & 5620 & 5416 & 4588 & 4040 & 3549 & 3426 \\
\hline Ferencszállás & 406 & 397 & 422 & 396 & 404 & 600 & 688 & 722 & 847 & 773 & 735 & 717 & 675 & 659 \\
\hline Földeák & 2574 & 3250 & 3846 & 4101 & 4425 & 4673 & 4488 & 4388 & 4522 & 4411 & 3782 & 3721 & 3489 & 3286 \\
\hline Királyhegyes & 877 & 1070 & 1284 & 1373 & 1437 & 1278 & 1336 & 1304 & 1436 & 1348 & 1090 & 902 & 793 & 692 \\
\hline Kiszonnbor & 3712 & 3707 & 3994 & 4108 & 4107 & 4329 & 5008 & 5177 & 5534 & 5240 & 4750 & 4577 & 4310 & 4247 \\
\hline Klárafalva & 331 & 333 & 430 & 554 & 570 & 583 & 599 & 597 & 646 & 531 & 591 & 553 & 509 & 470 \\
\hline Kóvegy & 605 & 609 & 798 & 755 & 837 & 934 & 901 & 930 & 860 & 844 & 697 & 584 & 476 & 462 \\
\hline Magyarcsanád & 2645 & 2897 & 3088 & 3025 & 3105 & 2981 & 2672 & 2593 & 2723 & 2544 & 2177 & 1931 & 1705 & 1638 \\
\hline Maroslele & 455 & 970 & 1430 & 1748 & 2172 & 2451 & 2772 & 2924 & 3077 & 2892 & 2312 & 2213 & 2183 & 2140 \\
\hline Nagyér & 669 & 779 & 966 & 1036 & 1011 & 1038 & 946 & 926 & 908 & 834 & 743 & 670 & 660 & 671 \\
\hline Nagylak & 0 & 0 & 0 & 0 & 355 & 416 & 784 & 1097 & 937 & 807 & 935 & 798 & 708 & 624 \\
\hline Óföldeák & 368 & 464 & 549 & 586 & 682 & 897 & 1056 & 1219 & 931 & 895 & 733 & 616 & 534 & 489 \\
\hline Pitvaros & 2257 & 2351 & 2645 & 2925 & 2936 & 3091 & 2978 & 2843 & 2162 & 2123 & 1778 & 1685 & 1575 & 1540 \\
\hline Makói kiśrégió & 51548 & 56471 & 63569 & 66490 & 69153 & 73645 & 73155 & 73823 & 70597 & 67437 & 61311 & 58497 & 53482 & 51335 \\
\hline $\begin{array}{l}\text { Csongrád megye } \\
\text { \%-ban }\end{array}$ & 19,1 & 19,7 & 19,4 & 18,3 & 17,5 & 18,1 & 17,2 & 17 & 16,5 & 15,6 & 13,8 & 12,8 & 12,2 & 11,8 \\
\hline
\end{tabular}

Forrás: Népszámlálás Csongrád megye 1990., Megyei Statisztikai Évönyv, 1994.

A trianoni határrendezés jelentős változásokat hozott a terület földrajzi helyzetében. Az egykori Csanád megye egy része Romániához került. Ez három települést (Nagylak, Sajtény és Tornya) érintett, de közülük Nagylak 10000 fö fölötti mezőváros volt. A 
Magyarországon maradt csonka Csanád vármegyéhez hozzácsatolták Torontál és Arad megye itt maradt részeit is (8 illetve 6 település), és az így keletkezett Csanád-AradTorontál közigazgatásilag ideiglenesen egyesített vármegye jóval nagyobb lett, mint az addigi Csanád vármegye. A megye szempontjából nem az tehát a fỏ probléma, hogy egyes részeit elvágták az országtól, hanem az, hogy a meglévő közlekedési, kereskedelmi kapcsolatokat szüntette meg a határ. Mindenekelőtt a megye keleti területeit vágta el természetes központjuktól, Aradtól, és ezt a szerepet Makó nem tudta átvenni. Másrészt és ez sem kevésbé fontos- a régió országhatár mellé, az ország perifériájára került.

Csanád-Arad-Torontál megye egészen 1950-ig megmaradt, amikor területét felosztották Csongrád és Békés megyék között. A Csongrád megyei részből megalakult a makói járás, esak a Szegedhez közeli, volt torontáli falvak kerültek a szegedi járáshoz. Az egykori Csanád vármegyét tehát a XX. század első felében kétszer is felosztották, és ezzel ha nem is egyedülálló, de speciális helyet foglal el az ország régiói között.

A makói kisrégió népességének növekedése 1920-ig töretlen: 1900 és 1920 között népessége újabb 11\%-kal növekedett. Ezalatt Csongrád megye 12\%-kal, tehát a terület tulajdonképpen a megyei átlagnak megfelelően gyarapodott. A jelentős változást az 1920as évtized hozta. Ekkor még minden településnek pozitív volt a természetes szaporodása, de 16 településből 13-ban vándorlási veszteség volt megfigyelhető, sőt kilenc településen köztük Makó városában - a vándorlási veszteség a természetes szaporodást is meghaladta. 1920 és 1930 között emiatt a régió népessége mintegy 500 fỏvel $(0,7 \%)$ csökkent. A települések csaknem fele, köztük Makó ekkorra már elérte népességmaximumát.

1930 és 1941 között a terület lakossága újra növekedett, (0,9\%-kal), Makó 1941-ben érte el a legkisebb arányt a terület népességéből, ekkor "mindössze" a térség népességének 47,2\%-a lakott Makón (összehasonlításképpen 1870-ben 52,2\%, 1900-ban 49,2\% volt ez az arány). Ugyanakkor a települések felénél szintén népességfogyás volt tapasztalható. Miközben a makói kisrégió népessége gyakorlatilag stagnált, Csongrád megye népessége 6,6\%-kal nőtt. Ennek oka a terület fó gazdasági alapjának, a mezőgazdaságnak a válsága.

A makói kisrégión belül a külterületi népesség aránya 1910-töl kezdve 20\% körül mozgott. Ez az arány is mutatja, hogy ez a régió nem igazi tanyás vidék. Ott inkább a kis területủ falvak a jellemzőek, mint a nagyhatárú mezővárosok (Makó kivételével). 1930ban a települések átlagterülete 4399 ha volt, ugyanez Csongrád megyében 9688 ha. A települések átlagos lélekszáma is csak $65 \%$-a az alföldinek. Ilyen kis határ mellett nem terjedt el a tanyarendszerú mủvelés, ez magyarázza a külterületi népesség alföldi үiszonylatban alacsony arányát. A települések közül 1930-ban nem volt külterületi lakos Klárafalván, Ferencszálláson és Királyhegyesen, viszont Nagylak teljes lakossága külterületen élt.

Ez természetesen abból adódik, hogy Nagylak belterülete Romániához került, és a Magyarországon maradt területeket még 1949-ben is külterületként tartják számon.

A lakosság kor szerinti összetételében 1900 és 1930 között jelentös változások zajlottak le. A gyermekkorúak (0-14 évesek) aránya 35,8\%-ról 25,4\%-ra csökkent, az öregkorúak (60-X évesek) aránya 6,8\%-ról 10,9\%-ra növekedett. Nagylak (újonnan alakult falu), yalamint a szlovák nemzetiségü falvak (Pitvaros, Csanádalberti) az átlagnál fiatalabbak, míg Makó városa, és Klárafalva (600 lakosú aprófalu) öregebbek. (2. táblázat)

A lakosság foglalkozási összetételében (3. táblázat) a mezőgazdasági keresők đomináltak a század egész első felében (1910-ben 70,7\%, 1930-ban 67,3\% a régió átlaga). A községek közül csaknem mindenhol 70\% fölötti a mezőgazdasági keresők aránya, míg Makón 55,2\%-ra esett vissza 1930-ig. Egyetlen kivétel van, Nagylak, ahol a keresőknek 
mindössze $24 \%$-a dolgozott a mezőgazdaságban. A falu területe nagyon csekély volt, illetve kendergyára felszívta a munkaeröt. Az iparban foglalkoztatottak aránya a 1910-es 15,2\%-ról 1930-ra 14,4\%-ra csökkent. Ennek is jelentös része kisüzemekben foglalkoztatott munkásokból tevődött össze. Húsz munkásnál többet foglalkoztató üzem összesen 10 volt a régióban, ebböl is 8 Makón, ahol az ipari foglalkoztatottak aránya $18 \%$ volt. Általában a nagyobb lakosságú kőzségek esetében kedvezőbb a lakosság foglalkozási szerkezete, magasabb az iparban, szolgáltatásokban (közlekedés) dolgozók aránya.

\section{TÁBLÁZAT}

A népesség korösszetétele a kissrégióban (\%)

(The population by ages in the small-region)

\begin{tabular}{|l|c|c|c|c|c|c|c|c|c|}
\hline Korcsoport & 1900 & 1910 & 1920 & 1930 & 1941 & 1960 & 1970 & 1980 & 1990 \\
\hline $0-14$ & 35,8 & 35,4 & 30,0 & 25,4 & 25,2 & 22,4 & 19,9 & 19,6 & 18,8 \\
\hline $15-39$ & 38,0 & 37,0 & 40,8 & 42,5 & 38,3 & 32,6 & 32,1 & 31,5 & 32,4 \\
\hline $40-59$ & 19,4 & 18,8 & 19,4 & 21,3 & 23,8 & 27,0 & 26,1 & 26,8 & 25,6 \\
\hline $60-\mathrm{X}$ & 6,8 & 8,8 & 9,8 & 10,9 & 12,6 & 18,0 & 21,9 & 22,1 & 23,2 \\
\hline
\end{tabular}

Forrás: Népszámlálás Csongrád megye 1990.

\section{TÁBLÁZAT}

Foglalkozási megoszlás (\%)

(The share of employment by main sectors)

\begin{tabular}{|l|c|c|c|c|c|c|r|}
\hline Ágazat & 1910 & 1930 & 1949 & 1960 & 1970 & 1980 & 1990 \\
\hline Mezögazdaság & 70,7 & 67,3 & 66,3 & 56,6 & 49,6 & 30,7 & 26,4 \\
\hline Ipar & 15,2 & 14,4 & 12,7 & 23,5 & 28,3 & 36,5 & 35 \\
\hline Tercier & 14,1 & 18,3 & 21 & 19,9 & 22,1 & 32,8 & 38,6 \\
\hline
\end{tabular}

Forrás: Népszámlálás Csongrád megye 1990.

A század elsó feléról összegzésképpen elmondható, hogy a kétszeri felosztás miatt a terủlet elöbb az ország, majd a megye perifériájára került, megindult a terủletről az elvándorlás, és ezzel megkezdődött a terület elöregedése. A terület végig mezőgazdasági jellegủ maradt, és ezzel együtt a foglalkozási átrétegződés is lassú maradt.

\section{A terület demográfiai átalakulása 1949 és 1990 között}

1949 után jelentős változások kezdỏdtek Magyarország társadalmában. A változás során nagy mértékben átalakult a lakosság foglalkozási összetétele, és ezt a népesség térbeli átrendeződése kísérte, elsỏsorban a községekbỏl a városok felé. A kérdés az, hogy joggal állíthatjuk-e, hogy a községekból a városokba tởrtént az áramlás. Általánosságban természetesen igaz ez az állítás, de sok olyan község van, amely szintén népességfelvevô szerepet játszott (kezdetben az ipari- és bányászfalvak, késỏbb a nagyvárosok formálódó agglomerációi). Másrészt léteznek olyan városok, amelyek viszont nem tudtak népességfelvevő centrumként funkcionálni, söt maguk is népesség-csökkenést 
könyvelhettek el. Az utóbbiak közé tartozik Makó is, aminek súlyos következményei voltak a terület egészére nézve.

A régiónak 1949-ben 70597, 1990-ben 53482 lakosa volt, népességének 24,2\%-át vesztette el. Igaz, sok olyan községe van az országnak, amelynek a népességvesztése ennél jóval nagyobb volt, de olyan városkörnyéke kevés, ahol a város és a hozzá kapcsolódó (kapcsolt) községek együttes népességvesztése csaknem 25\%-os.

$\mathrm{Az}$ egyes települések esetében azonban jelentős különbségek vannak a népességvesztés mértékében. A legkevésbé Makó lakossága csökkent 1949 óta, népességének 16,8\%-át vesztette el. Ez azonban 5539 föt jelent, vagyis azt, hogy Magyarországon 1949 óta Makónak csökkent legtöbbel a lakossága! Ugyanakkor valamennyi község népességfogyása $20 \%$ felett volt. A legkisebb értéket a Szegedhez, illetve Hódmezövásárhelyhez közeli települések esetében tapasztaltunk (Ferencszállás, Klárafalva, Kiszombor, Földeák), melynek oka a relatíve, vagy ténylegesen jó közlekedési helyzetükben keresendö. Kevésbé fogyott Nagylak népessége is, amelyben szerepet játszottak az ott lévó ipari munkahelyek. Ugyancsak az átlag alatti fogyást mutatott Pitvaros, és két szomszédos falu: Ambrózfalva és Nagyér. Szerepet játszhatott ebben: a relatíve jó közlekedési helyzet, Mezőhegyes, Tótkomlós és Orosháza felé (autóbusszal Nagyérről Tótkomlós 7, Mezőhegyes 20, Orosháza 38, Makó pedig 43 percre van), a lakosság nemzetiségi összetétele, azaz szlovák falvak (1930-ban Pitvaros 91\%-ban, Ambrózfalva 88\%-ban szlovák), a lakosságcserével 1949-re már mobilizálható népességük jelentös részét elvesztették. A szlovák etnikum természetes szaporodása valamivel magasabb, mint a magyaroké, és nincs Magyarországon jelentös szlovák lakosságú központ (Békéscsabán jóval több a magyar, mint a szlovák, Tótkomlós pedig az intézmények hiánya miatt nem központ), így a migráció a nemzeti identitás elvesztését is jelentette volna.

Az 1960-as évtizedre az ország természetes szaporodása erősen visszaesett, ugyanígy a makói kisrégióé is, de itt ez a csökkenés már elegendő volt ahhoz, hogy természetes fogyás következzen be $(1,5 \%)$. Az országosan is csökkenő természetes szaporodás, és az előzó évtizedre jellemző elvândorlás miatt elkezdődött egy azóta is tartó folyamat, a régió népességének természetes fogyása. (Mindössze Nagylakon és Nagyéren pozitív 1960-ban a természetes szaporodás).

A vándorlási egyenleg továbbra is negatív, de az előző évtizedhez képest valamelyest mérséklődött (6,6\%). Mindössze Klárafalván (Szegedhez való közelség, és jó közlekedés), és Nagylakon (ipari munkahely) pozitiv a vándorlási egyenleg. Megállapítható, hogy az előzö évtizedhez képest a Szegedhez közeli településeken mérséklődőtt, a régió keleti felében lévő telepưléseken pedig erősödött az elvándorlás. Egyes falvak vándorlási vesztesége $20 \%$ feletti, söt Csanádalbertié $46 \%(!)$, melynek okai a kedvezötlen mezőgazdasági adottságok - nagyon kis terület - , és az árnyékos közlekedési helyzet. Makó vándorlási vesztesége mérséklődött, így népességvesztése kisebb a körzet átlagánál.

Az 1970-es évekre országosan is, és a makói kisrégióban is minimálisan csökkent a természetes szaporodás (a térségben:-1,7\%). Makó természetes szaporodási mutatója javult, a községeké romlott, így kiegyenlitődés volt közöttük. Pozitív természetes szaporodás volt Klárafalván és Nagylakon, ott, ahol az elóző évtizedben vándorlási nyereséget regisztráltak. Ebben az évtizedben kirajzolódott a terület három jelenlegi katasztrófális demográfịai helyzetben lévő települése is, Kövegy és Csanádalberti esetében 8 , Óföldeák esetében $18 \%$-os volt a népességfogyás. A makói kisrégióban volt a megye településeinek 29 , addig a természetesen fogyó településeinek $47 \%$-a. 
A vándorlási veszteség az elöző évtizedekhez képest csökkent $(2,4 \%)$, hiszen a legviharosabb átalakulási folyamatok (extenzív iparosítás, TSZ-esítés) már lezajlottak. Ebben a dekádban vándorlási nyeresége volt Óföldeáknak (szociális otthon), illetve minimális $(0,5 \%)$ Makónak. Így bár Makó növelte a térségen belüli részarányát (1970: $49,4 \%, 1980: 51,1 \%$ ), de jelentős népességfelvevővé nem tudott válni.

A nyolcvanas évekre a természetes fogyás 6,1\%, amely, mint 1949 óta mindig kb. 5\%kal volt az országos érték alatt. A vándorlási veszteség tovább mérséklödött $(-1,9 \%)$. A régió összes településén természetes és tényleges fogyás volt megfigyelhetö, és vándorlási aktívum is csak Kiszomboron, Maroslelén és Óföldeákon. A régió tenyleges fogyása 8,0\%, csaknem annyi, mint a hatvanas években, de ennek háromnegyede már a természetes fogyásból származik, és ennek komoly hatásai lesznek pl. a korstruktúrára, vagy lehetnek a terület dinamizmusára.

A makói kisrégió 1870-ben a mai Csongrád megye lakosságának 19,1\%-át koncentrálta, 1930-ban 17,2\%-át, 1949-ben 16,5\%-át, még 1990-ben 12,2\%-át. Ha a települések jelenlegi (1990-es) közigazgatási területét vizsgáljuk, akkor Makó 1870-ben a jelenlegi országterület 10. legnagyobb települése volt, söt 1890-ben 9. Ezzel szemben 1930-ban már csak a 18., 1949-ben 19., és 1990-re a 44, helyre esett vissza.

A térség foglalkoztatási szerkezete jelentösen átalakult 1949 után. Megindult a mezögazdasági népesség csökkenése, így 1990-ben már csak a régió keresőinek 26,4\%-a dolgozott a szektorban (32700 fös csökkenés). Általánosságban elmondható, hogy minél rosszabb egy település közlekedési helyzete, annál nagyobb a mezögazdasági keresök aránya (1990-ben Kövegy: 49\%,Királyhegyes: 49\%, Csanádalberti: $47 \%$ ), és fordítva (Klárafalva: $16 \%$, Ferencszállás: $23 \%$, Kiszombor: $24 \%$ ). Az ipari keresők aránya többszörösére nött (1949-ben 12,7\%, 1980-ban 36,5\% volt). A nyolcvanas években itt is megindult az ipari keresők arányának csökkenése (1990: 35,0\%). Nagylak aránya továbbra is kimagasló (1990: 59,9\%), de ez már messze elmarad az 1970-es 77,7\%-tól. A tercier szektorban dolgozók aránya is emelkedett (1949: 21,0\%, 1990: 38,6\%). 1980-ra Ferencszálláson és Kiszomboron, majd 1990-re Makó, Csanádpalota és Óföldeák esetében is a tercier szektor volt a legerősebb. Összefoglalásként elmondható, hogy a makói kisrégió foglalkozási szerkezetében ugyanazok a folyamatok játszódnak le, mint országosan, csak mintegy negyedszázados késéssel.

$\mathrm{Az}$ 1949-1990 között eltelt időszakról összefoglalás képen elmondható, hogy zuhanásszerüen csökkent a lakosság száma megnőtt az öregkorúak aránya, szinte eltünt a külterületi lakosság, s a felénél is kevesebbre süllyedt a mezögazdasági keresők aránya.

\section{A makói kistérség a rendszerváltás után}

A makói kisrégió népességcsúcsa 1941-ben volt, és 1990-ben 20341, 1994-ben pedig 22488 fövel élt kevesebb ember a régióban, mint a népességcsúcs idején. 1949 óta az óriási elvándorlás mellett több, mint 4000 fở tett ki a természetes fogyás. A térség települései közül kilencben kevesebben éltek 1990-ben, mint 1870-ben, söt 1994-re már Makó népessége is az 1870-es szint alá csökkent. A Makótól keletre eső települések Nagylak kivételével mind az elöző csoportba tartoznak. 1980 és 1990 között minden településen természetes fogyás volt megfigyelhetö.

1994-re a terület népessége 51335 före csökkent, vagyis négy év alatt újabb 2147 föt vesztett a régió. Ez évi 10,1\%o tényleges fogyás, nagyobb, mint korábban bármikor. A 
megye 52 községéből tíznek nőtt 1990 óta a lakossága, ebböl nyolc Szegeddel határos, ezenkívül az egyik, jelesül Nagyér a vizsgált területen van. A falu népességnövekedése 1,7\% vagy 11 fö. Ezzel szemben három község (Csanádalberti, Királyhegyes és Nagylak) népességének több, mint 10\%-át elvesztette ez alatt a négy év alatt, tehát megállapíthatjuk, hogy a terület népességének fogyása közel sem állt még meg.

A területünkön nem csak az a probléma, hogy a községek a lakosságuk 30\%-át elvesztették az elmúlt 40 évben, hiszen ez általános jelenség nemcsak az egész Alföldön, de az egész országban is, hanem az is, hogy a terület központjának is közel $20 \%$-kal csökkent a népessége! Vizsgáljuk meg néhány olyan települést, amely Makóhoz hasonlóan szintén nem kapott jelentős ipart, és esetleg a járási székhely adminisztratív szerepkörén kívül nem volt más funkciója. 1949 óta Mezőtúr 11\%-ot, Csongrảd 13\%-ot, Kiskunmajsa 23\%-ot, Túrkeve 24\%-ot vesztett, népességéból. Makó népességfogyásának a 40\%-a azonban a természetes fogyásból származik, és csak a többi $60 \%$ az elvándorlásból.

Okozhatja ezt az elvándorlást Makó és Szeged kapcsolata is. Szeged, mint megyeszékhely ipari és szolgáltató szerepkörei révén jelentős vonzást gyakorolt a megye többi településére. Ahhoz Makó túl távol volt, hogy beépüljön Szeged éppen kialakulóban lévó agglomerációjába, és túl sok volt a felesleges munkaereje ahhoz, hogy ezek az emberek naponta Szegedre ingázzanak. (A Szegedre bejáró összes ingázó 1990-ben 13571 fó volt, így ezt az esetleges 3-4000 makói ingázót nem szívhatta fel a város.

Ahhoz túl közel van Szegedhez Makó, hogy egy szubcentrummá formálódjon, mint ahogyan Szentesnek ez többé-kevésbé sikerült Szeged szívóhatását bizonyítja a következö adat: a közvetlen Makó mellett lévő Kiszomborból (Makótól 5, Szegedtől 25 km) csaknem annyian ingáztak 1990-ben Szegedre (393), mint Makóra (429).

A munkanélküliségi ráta a makói kisrégióban 1990 és 1994 között végig magasabb volt, mint a Csongrád megyei átlag. (A megyei értéket csökkenti Szeged a maga nagy népességsúlyával, és alacsony munkanélküliségével.) Azonban a makói kisrégió munkanélkülisége a Szeged nélküli megyei értéknél is magasabb. A terület munkanélküliségi rátája 1990 januárjában 2,6\% volt, ez 1992 augusztusára 17,2\%-ra nött. Ezután lassú növekedés, majd pedig csökkenés következett, nem utolsó sorban azért, mert sokan már kikerültek a regisztrációból. Mivel a népesség jelentős része ingázott (1990-ben 6823 munkahely, és 10827 aktív kereső), így az "ingázók által betöltött" munkahelyek leépítése érzékenyen érintette a területet. Makó ipari üzemeinek jelentős része nem helyi irányítású volt, így a vidéki ipar válsága is jelentős mértékben sújtja a területet.

A régión belül településszinten azonban jelentős különbségek vannak. A területen belüli munkanélküliségi ráták szórása 1992-ig nött (10\%-os legalacsonyabb, és $31 \%$-os legmagasabb érték), azután csökkent (1994 szeptemberben 7, illetve 18\%-os szélsőértékek). Makó mutatója mindvégig magasabb, mint a régió átlaga. Egyes települések (Csanádalberti, Magyarcsanád) mindvégig magas értékekkel tủnnek ki, az ingazók igen nagy száma, és kedvezötlen összetétele miatt (ipari, fizikai dolgozók). Hasonló helyzetben van Királyhegyes, ahol a munkanélküliségi ráta 1992 augusztusában $30 \%$ felett volt. Végig alacsony értékek jellemzik Klárafalva, Ferencszállás, Kiszombor községeket (Szegedhez való jó kapcsolat), valamint Óföldeákot a kevés aktív keresỏ és a szociális otthon, mint stabil munkahely miatt.

A gazdaság állapotát másik oldalról szemlélteti az újonnan alakuló gazdasági társulások száma, vagy ezeknek a lakosság nagyságához viszonyított értéke. A makói kisrégió ebben a tekintetben is lemaradni látszik, hiszen a Csongrád megyei városok közül éppen Makón jut legkevesebb gazdasági társulás megfelelö lakosra. Így a gazdaság dinamizálódásában 
még megyei szinten is lemarad Makó, és ha továbbra sem fog ilyen tekintetben dinamizálódni, akkor várható Makónak, és ezzel együtt térségének további lemaradása.

A makói kisrégió népessége várhatóan továbbra is csökkenni fog, a természetes fogyás és az elvándorlás miatt. Makó városának többirányú fejlesztésére lenne szükség. De milyen irányú fejlesztésre? A mezőgazdaság önmagában biztosan nem elegendő, a feldolgozóipar fejlesztése is szükséges. Makó szolgáltató funkcióinak bövítése is fontos lenne, hogy jobban elláthassa a környező községeket, tényleges központjává váljon vidékének. Ugyanakkor Makó és a községek közötti közlekedés is fejlesztésre szorul.

A térség településeinek más-más problémákkal kell szembenézniük. Legkedvezőbb a Szeged és Makó közti falvak helyzete, ezek még népességük gyarapitására is képesek lehetnek. Azoknak a falvaknak, amelyek Makó és Hódmezỏvásárhely között találhatóak, már kérdésesebb a jövőjük, hiszen ezek a központok kevésbé dinamikus, sajátos csoportot alkotnak a 43-as foút mentén a Makótól keletre lévő települések, ahol a tranzitforgalom és a későbbiekben a határmentiség, a határátlépő hozhat fellendülést. A legnehezebb helyzetben a régió északkeleti, forgalmi árnyékban lévó falvai vannak, melyek saját forrásaikra támaszkodva nem léphetnek tovább, demográfiai helyzetük várhatóan nem javul.

\section{Irodalom}

Becsei J. (1993) A Békés-Bihari határmenti kistérség társadalmi-foglalkozási szerkezete. Mühely 1993/10. Közép-és Kelet-Európai Gazdaság- és Környezetfejlesztési Intézet és Környezetvédelmi és Terulletfejlesztési Minisztérium. 1-27. o.

Csongrád megye gazdasági földrajza.(1983) (Főszerk.: Krajkó Gyula) Szeged 465. o.

Erdei F. (1971) Város és vidéke. Magyarország felfedezése. Szépirodalmi Könyvkiadó, Budapest. 451. o.

Erdei F. (1977) Telepuléspolitika, közigazgatás, urbanizáció. Összegyüjtött irások és beszédek. Akadémiai Kiadó, Budapest. 558. o.

Erdei F. (1982) Makó társadalomrajza. A Makói Múzeum Füzetei, 27. Makó. 1-19. o.

Gazdasági, társadalmi folyamatok és a kistérségek szervezỏdése Csongrád megyében. (1993) (Szerk.: Mészáros Rezsö) JATEPress, Szeged. 144. o.

Kiss L. (1988) Földrajzi nevek etimológiai szótára l-II. Akadémiai Kiadó, Budapest.

Magyar városok monográfiája. Makó és Csanád-Torontál vármegyei községek. 1929. (Szerk: Barna János) A magyar városok monográfiájának kiadóhivatala, Budapest 406. 0.

Tóth J. (1977) Az urbanizáció népességföldrajzi vonatkozásai a Dél-Alföldön. Földrajzi Tanulmányok, 14. Akadémiai Kiadó, Budapest. 142. o.

\section{Abstract}

The quiet and smooth development of the Makó small-region were interrupted by some traumas in the last 125 years. Fristly after Trianon, secondly after the Parisian peacecongress it become a peripheral area near the state borders. This situation looks a longlasting process. This traditional agrar-area and it's development were under the inluence of the industrializing in the fifties, and organizing cooperatives in the early sixties. In the last decades this small-region developed in the shadow of Szeged - one of the some regional centres of Hungary - shows a real dinamic progress.

The study shows the development way of a small area, near the state borders, with a weak domain city (Makó) as the centre of the region. It flashed up the endogenous resources which the region can mobilize, to break out of the recent critical part of the population decrease. 